\title{
IDENTIFICATION OF LOCAL RICE GENOTYPES FROM DELI SERDANG, NORTH SUMATERA, INDONESIA TO DROUGHT STRESS CONDITION
}

\author{
Noverina Chaniago ${ }^{1,2}$, Irfan Suliansyah ${ }^{3}$, Irawati Chaniago*,3, Nalwida Rozen ${ }^{3}$ \\ ${ }^{1}$ Department of Agricultural Science, Faculty of Agriculture, Universitas Andalas, Indonesia \\ ${ }^{2}$ Department of Agrotechnology, Faculty of Agriculture, Universitas Islam Sumatera Utara, Indonesia \\ ${ }^{3}$ Department of Agrotechnology, Faculty of Agriculture, Universitas Andalas, Indonesia \\ *Corresponding author \\ Email: irawati@agr.unand.ac.id
}

\begin{abstract}
Deli Serdang regency in North Sumatera, Indonesia has a high diversity of local rice that has adapted to various climatic and edaphic conditions including drought. Studies on tolerance level of various local rice genotypes to drought are important to be carried out. This will help plant breeders with germplasms to support rice breeding program. Polyethylene glycol (PEG) is a water-soluble compound with high osmotic pressure and unlikely to have specific interaction with biological, chemicals and often to be used in the studies of drought stress in plants. This experiment was aimed to determine tolerance level of local rice genotypes from Deli Serdang, North Sumatera, Indonesia to drought stress. A completely randomized design (CRD) with 3 replicates were used in this study. The first factor was 23 local rice genotypes and 4 tolerance genotypes to drought stress and the second factor was PEG 6000 concentration i.e 0 and 20\% $(w / v)$. The percentage of germination, plant height, length and number of roots protruding from paraffin-wax layer, seedling fresh and dry weight, index of tolerance, probability of resistance, and leaf proline content were measured in this study. Based on morphological and physiological characters that measured in this study six local rice genotypes, namely Gemuruh, Ramos Merah, Arias, Sialus, Silayur, and Sirabut were categorized as tolerance to drought stress. These resistant local rice genotypes were potential to be used for further drought stress studies in paddy field.
\end{abstract}

Keywords: local rice; Deli Serdang; drought stress; tolerant

\section{Introduction}

A landrace is a very valuable genetic asset and need to be managed properly. Landrace has been cultivated for generations and has adapted well to various climatic conditions. Deli Serdang Regency in North Sumatera, Indoneasi has a diversity of rice local that found in several villages. However, management and utilization of the rice's germplasm are still very low which, in the long run, may result in a reduction and extinction of the germplasm. This low management and utilization of local rice is resulted from low availability if the local rice as well as limited number of farmers growing the rice. Therefore, attempts should be made to preserve this germplasm collection such as characterization of the existing local rice and improving the characters to become new superior varieties (Neeraja et al., 2006).

The distribution of plant species across places and various environmental conditions is often determined by exposure to environmentally-driven stress such as drought. Plant response to environmental stress may vary and occurs at different organization levels, from morphological, anatomical, cellular, biochemical, and molecular levels (Manavalan et al., 2009; Muñoz \& Quiles, 
2013). Drought is one of the most serious limiting factor for rice growth and has resulted in a significant decline in rice productivity (Sabar \& Arif, 2014). Drought may affect various stages of plant growth and development such as seedling vigor (Singh et al., 1999), root depth and density (Ludlow \& Muchow, 1990; Manavalan et al., 2009), and flowering (Bolaños \& Edmeades, 1996). Plant morphological changes such as lengthen roots occurred during drought stress. Roots grew deeper and reached soil depth for over $20 \mathrm{~cm}$ below the surface (Allah et al., 2010) and this to help plants to reach water for their growth during the shortage of water (Sujinah \& Jamil, 2016).

Proline content has been widely used as an indicator of plant response to drought (Barunawati et al., 2016). Proline is an amino acid that plays important role in preserving nitrogen, acting as an osmo-regulator, and protecting certain enzymes. Proline levels were found to increase in response to drought stress in the various crops, such as maize (Yang et al., 2014), wheat (Barunawati et al., 2016) and rice (Purbajanti et al., 2017; Zain et al., 2014). Proline keeps cell turgor pressure and supporting root growth during drought (Zivcak et al., 2016).

Polyethylene Glycol (PEG) has been widely used in the study of water stress in plants including rice (Choi et al., 2000; Swapna \& Shylaraj, 2017). PEG is an inert chemical compound, non-toxic, and has a high molecular weight (Jiang \& Lafitte, 2007), increases the osmotic potential of growing medium that may reduce the amount of water intake of seedlings (Jatoi et al., 2014). Studies in screening of local rice genotypes from Deli Serdang, North Sumatera, Indonesia to drought stress has not yet reported. The experiment reported here used PEG to mimic water stress during the growth and development of rice that collected from Deli Serdang, North Sumatera, Indonesia. The experiment aimed to determine tolerance level of local rice genotypes from Deli Serdang, North Sumatera, Indonesia to drought stress. Some morphological and physiological characters were observed in this study.

\section{Methods}

\subsection{Rice Genotype Materials}

Experiments were carried out at Laboratory of Plant Physiology and glasshouse of Faculty of Agriculture, Universitas Islam Sumatera Utara, Medan, from February to April 2020. Twentythree (23) local rice genotypes from Deli Serdang, North Sumetera, Indonesia were subjected to the experiment. Four (4) rice varieties categorized as tolerant to drought stress were included as control. A two-way factorial design with 27 rice genotypes and two levels of PEG concentrations were assigned. Local rice genotypes were $\operatorname{Kuku}$ Balam $\left(\mathrm{G}_{1}\right)$, Siudang $\left(\mathrm{G}_{2}\right)$, Pandan Wangi $\left(\mathrm{G}_{3}\right)$, Sigambiri Merah $\left(\mathrm{G}_{4}\right)$, Sigantang $\left(\mathrm{G}_{5}\right)$, Sibelacan $\left(\mathrm{G}_{6}\right)$, Gemuruh $\left(\mathrm{G}_{7}\right)$, Sipingkol $\left(\mathrm{G}_{8}\right)$, Beras Hitam $\left(\mathrm{G}_{9}\right)$, Sipirok $\left(\mathrm{G}_{10}\right)$, Merah Wangi $\left(\mathrm{G}_{11}\right)$, Serang $\left(\mathrm{G}_{12}\right)$, Ramos Putih $\left(\mathrm{G}_{13}\right)$, Ramos Merah $\left(\mathrm{G}_{14}\right)$, Arias $\left(\mathrm{G}_{15}\right)$, Maraisi Merah $\left(\mathrm{G}_{16}\right)$, Sigambiri Putih $\left(\mathrm{G}_{17}\right)$, Sijambi $\left(\mathrm{G}_{18}\right)$, Tambur Kersik 
$\left(G_{19}\right)$, Sialus $\left(G_{20}\right)$, Silayur $\left(G_{21}\right)$, Sirabut $\left(G_{22}\right)$, Sigimbal $\left(G_{23}\right)$. In this study, four rice varieties i.e Inpago $8\left(\mathrm{G}_{24}\right)$, Inpago $10\left(\mathrm{G}_{25}\right)$, Inpago $11\left(\mathrm{G}_{26}\right)$ dan Inpari $39\left(\mathrm{G}_{27}\right)$ as categorized as tolerant to drought stress were used as control.

\subsection{Germination Test}

Surface sterilization of rice seeds. Rice seeds were washed with running tap water. The seeds were then washed with distilled water for three times followed by washing in $70 \%$ ethanol for 30 seconds. The seeds were then washed with $2 \% \mathrm{NaOCl}$ for 15 minutes. The sterilised seeds were immediately washed 4 times with distilled water to get rid of all traces of sterilant and were left to dry at room temperature.

Seed germination. The rice sterilized seeds were soaked in 20\% PEG solution (PEG 6000, Sigma-Aldrich, Steinheim, Germany) for 60 minutes. Ten seeds were then placed in a $60-\mathrm{mm}$ diameter Petri dish with $2 \mathrm{~mL}$ of $20 \%$ PEG and were kept for germination at room temperature for 7 days. The control treatment group used sterile water to wet the germinating medium ( $0 \%$ PEG). Germination percentage was counted at 7 days after planting.

\subsection{Early Growth of Rice with PEG}

Early growth of rice seedling was observed in a double pot-growing media. Pre-germinated rice was transferred onto pots containing paraffin and vaseline mixture $(6: 4, \mathrm{w} / \mathrm{w})$. The mixture was preheated at $70^{\circ} \mathrm{C}$ and was then poured into a perforated-base plastic pot and let to dry. The solid paraffin and vaseline mixture of $3 \mathrm{~mm}$ thick was used as a basal bedding of potting mixture onto which $200 \mathrm{~g}$ of soil and sand mixture $(1: 1 ; \mathrm{w} / \mathrm{w})$ was added. Two pre-germinated rice seedlings with a $1-\mathrm{cm}$-long radicle were planted at each pot. Another plastic pot containing $45 \mathrm{~mL}$ of Hoagland's nutrient solution (Harper \& Nicholas, 1976) was prepared. The pot containing rice seedlings was carefully stacked into a nutrient solution pot so that the base of the seedling pot did not reach the nutrient solution. The pots were carefully placed at a wooden rack in a glass house and were kept for 4 weeks. Each pot was watered every day with $7 \mathrm{~mL}$ of distilled water.

\subsection{Measurement and Data Collection}

Data on plant responses to drought stress were recorded at 28 days after transplanting. Data collection includes plant height $(\mathrm{PH})$, number of roots protruding from the paraffin layer $(\mathrm{RN})$, length of roots protruding from the paraffin layer (RL), and plant fresh and dry weight (following hot-air dried at $70^{\circ} \mathrm{C}$ for 48 hours to get a constant weight of plant tissue), stress tolerant index (Iriany et al., 2005), resistance probability, and leaf proline content. The probability of resistance $(\%)$ is calculated using a curve of normal standard graph. Total values of area below the curve were used for the calculation following (Sauro, 2007). 
The measurement of proline content was conducted as follows: $0.5 \mathrm{~g}$ of leaves were extracted with $3 \mathrm{~mL}$ of $3 \% 5$-sulphosalicylic acid in a mortar. The leaf extract was then centrifuged at $21,000 \times g$ for $15 \mathrm{~min}$. The clear supernatant was carefully poured into a glass vial prior to adding $2 \mathrm{~mL}$ of 5-sulphosalicylic acid to the residue. The mixture was centrifuged for a second time. The second supernatant was poured onto the first supernatant and was thoroughly mixed (so-called a final supernatant). Two $\mathrm{mL}$ of the final supernatant was mixed with $2 \mathrm{~mL}$ of $3 \%$ ninhydrin reagent and $2 \mathrm{~mL}$ of acetic acid glacial. The mixture was then heated at $100^{\circ} \mathrm{C}$ for 1 hour in a water-bath and was cooled in an ice bath. Four mL of toluene was added to the mixture and was mixed for 15 seconds. Absorbance value of the mixture was measured at $520 \mathrm{~nm}$ in a spectrophotometer. The proline content of the leaf was expressed in $\mu \mathrm{M} / \mathrm{g} \mathrm{FW}$ (fresh weight of leaves) (Larkunthod et al., 2018).

The tolerance index (TI) was obtained using the following equation (1):

$$
T I=\frac{Y d}{Y n} x \frac{Y d}{H y d}
$$

where $Y d$ and $Y n$ respectively represent observed variables under drought and normal conditions. Hyd is the highest observed variable under drought conditions. $\mathrm{TI}>0.5=$ tolerant and $\mathrm{TI}<0.5=$ susceptible (Fernandez, 1993, as cited in Iriany et al., 2005).

\subsection{Data Analysis}

Analysis of variance was applied to the data and mean separation was calculated according to Duncan's New Multiple Range Test at 5\% level. If only the effect of PEG was found to be significant, then mean separation was calculated as for t-Dunnet at $5 \%$.

Table 1. Analysis of variance of 23 landrace rice of Deli Serdang district and 4 rice varieties tolerant to drought (germination percentage (GP), plant height $(\mathrm{PH})$, length of roots protruding from the paraffin layer (RL), and number of roots protruding from the paraffin layer (RN), fresh weight (FW) and dry weight (DW) of plants

\begin{tabular}{lllllll}
\hline $\begin{array}{l}\text { Source of } \\
\text { Variance }\end{array}$ & GP & PH & RL & RN & FW & DW \\
\hline Genotype (G) & $16.05^{*}$ & $4.75^{*}$ & $20.83^{*}$ & $2.94^{*}$ & $21.03^{*}$ & $16.18^{*}$ \\
PEG (P) & $855.95^{*}$ & $3.83^{*}$ & $19.90^{*}$ & $1.75^{\text {ns }}$ & $539.87^{*}$ & $83.97^{*}$ \\
G x P & $36.45^{*}$ & $0.17^{\text {ns }}$ & $14.18^{*}$ & $6.17^{*}$ & $27.45^{*}$ & $17.67^{*}$ \\
\hline
\end{tabular}

Remarks: * (significant); ns (not significant)

\section{Results and Discussion}

The summary of analysis of variance on various observations demonstrated different responses to water stress induced by $20 \%$ PEG. Responses of germination percentage (GP), plant height $(\mathrm{PH})$, length of roots protruding from the paraffin layer $(\mathrm{RL})$, and the number of roots protruding from the paraffin layer (RN), fresh weight (FW), and dry weight (DW) of plants are presented in Table 1. Rice genotypes $(\mathrm{G})$ significantly affected all variables observed. Water stress $(\mathrm{P})$ affected all variables but the number of roots protruding from the paraffin layer $(\mathrm{RN})$. The interaction 
between rice genotypes and water stress only affected germination percentage (GP), length of roots protruding from the paraffin layer $(\mathrm{RL})$, and the number of roots protruding from the paraffin layer $(\mathrm{RN})$, fresh weight $(\mathrm{FW})$, and dry weight (DW) of rice plants.

\subsection{Germination Percentage}

Various germination percentages resulted in different tolerance and probability of resistance towards water stress under the experimental condition (Table 2).

All rice genotypes showed $100 \%$ of germination in $0 \%$ PEG except for $\mathrm{G}_{1}, \mathrm{G}_{2}$, and $\mathrm{G}_{4}$. These three rice genotypes showed very low germination which might be resulted from low seed viability as the seeds had been stored for 6 months after collecting from the field. In contrast, treatment of 20\% PEG reduced germination and the response varied within genotypes. interestingly our study showed that there were 4 local rice genotypes $\left(\mathrm{G}_{14}, \mathrm{G}_{16}, \mathrm{G}_{21}\right.$, and $\left.\mathrm{G}_{22}\right)$, germinated similar or higher than that of tolerant rice varieties. These 4 local rice genotypes demonstrated their potential to be tolerant to drought with a tolerant index of $>0.5$.

Table 2. Germination percentage, tolerant index, and the resistant probability of 23 genotypes of local rice in Deli Serdang district and 4 varieties of drought-tolerant in response to PEG

\begin{tabular}{|c|c|c|c|c|c|c|}
\hline \multirow[t]{2}{*}{ Genotype } & \multicolumn{2}{|c|}{$\begin{array}{c}\text { Germination } \\
\text { percentage }(\%)\end{array}$} & \multirow[t]{2}{*}{$\begin{array}{l}\text { Genotype } \\
\text { Mean }\end{array}$} & \multirow[t]{2}{*}{$\begin{array}{l}\text { Toleranc } \\
\text { e Index }\end{array}$} & \multirow[t]{2}{*}{ Criteria } & \multirow{2}{*}{$\begin{array}{c}\text { Resistant } \\
\text { Probability } \\
(\%)\end{array}$} \\
\hline & PEG $0 \%$ & PEG $20 \%$ & & & & \\
\hline Kuku Balam (G1) & $20.00 \mathrm{~m}$ & $13.33 \mathrm{n}$ & $16.67 \mathrm{~m}$ & 0.10 & Susceptible & 20.80 \\
\hline Siudang (G2) & $33.33 \mathrm{k}$ & $13.33 \mathrm{n}$ & 23.331 & 0.06 & Susceptible & 6.20 \\
\hline Pandan Wangi (G3) & $100.00 \mathrm{a}$ & $53.33 \mathrm{i}$ & $76.67 \mathrm{e}$ & 0.31 & Susceptible & 60.95 \\
\hline Sigambiri merah (G4) & $53.33 \mathrm{i}$ & $20.00 \mathrm{~m}$ & $36.67 \mathrm{k}$ & 0.08 & Susceptible & 13.50 \\
\hline Sigantang (G5) & $100.00 \mathrm{a}$ & $33.33 \mathrm{k}$ & $66.67 \mathrm{~g}$ & 0.12 & Susceptible & 24.45 \\
\hline Sibelacan (G6) & $100.00 \mathrm{a}$ & $60 . .00 \mathrm{~h}$ & $80.00 \mathrm{~d}$ & 0.38 & Susceptible & 64.60 \\
\hline Gemuruh (G7) & $100.00 \mathrm{a}$ & $53.00 \mathrm{i}$ & $76.67 \mathrm{e}$ & 0.30 & Susceptible & 42.70 \\
\hline Sipingkol (G8) & $93.33 \mathrm{~b}$ & $40.00 \mathrm{j}$ & $66.67 \mathrm{~g}$ & 0.18 & Susceptible & 39.05 \\
\hline Padi Hitam (G9) & $100.00 \mathrm{a}$ & 26.661 & $63.33 \mathrm{~h}$ & 0.07 & Susceptible & 9.85 \\
\hline Sipirok (G10) & 80.00 e & $13.33 \mathrm{n}$ & $46.67 \mathrm{j}$ & 0.02 & Susceptible & 2.55 \\
\hline Merah Wangi (G11) & $100.00 \mathrm{a}$ & $53.33 \mathrm{i}$ & $76.67 \mathrm{e}$ & 0.30 & Susceptible & 46.35 \\
\hline Serang (G12) & $100.00 \mathrm{a}$ & $60.00 \mathrm{~h}$ & $80.00 \mathrm{~d}$ & $0 . .38$ & Susceptible & 68.25 \\
\hline Ramos Putih (G13) & $100.00 \mathrm{a}$ & $53.33 \mathrm{i}$ & $76.67 \mathrm{e}$ & 0.30 & Susceptible & 50.00 \\
\hline Ramos Merah (G14) & $80.00 \mathrm{~d}$ & $93 . .33 \mathrm{~b}$ & $88.33 \mathrm{~b}$ & 0.55 & Tolerant & 75.55 \\
\hline Arias (G15) & $100.00 \mathrm{a}$ & $33.33 \mathrm{k}$ & $66.67 \mathrm{~g}$ & 0.12 & Susceptible & 28.10 \\
\hline Maraisi (G16) & $100.00 \mathrm{a}$ & $73.33 \mathrm{f}$ & $86.67 \mathrm{~b}$ & 0.57 & Tolerant & 79.20 \\
\hline Sigambiri Putih (G17) & $100.00 \mathrm{a}$ & $40.00 \mathrm{j}$ & $70.00 \mathrm{f}$ & 0.17 & Susceptible & 31.75 \\
\hline Sijambi (G18) & $100.00 \mathrm{a}$ & $53.33 \mathrm{i}$ & $76.67 \mathrm{e}$ & 0.30 & Susceptible & 53.65 \\
\hline Tambur Kersik (G19) & $100.00 \mathrm{a}$ & $40.00 \mathrm{j}$ & $70.00 \mathrm{f}$ & 0.17 & Susceptible & 35.40 \\
\hline Sialus (G20) & $93.33 \mathrm{~b}$ & 26.661 & $60.00 \mathrm{i}$ & 0.08 & Susceptible & 17.15 \\
\hline Silayur (G21) & $100.00 \mathrm{a}$ & $73.33 \mathrm{f}$ & $86.67 \mathrm{~b}$ & 0.57 & Tolerant & 82.25 \\
\hline Sirabut (G22) & $100.00 \mathrm{a}$ & $73.33 \mathrm{f}$ & $86.67 \mathrm{~b}$ & 0.57 & Tolerant & 86.50 \\
\hline Sigimbal (G23) & $100.00 \mathrm{a}$ & $53.33 \mathrm{i}$ & $76.67 \mathrm{e}$ & 0.30 & Susceptible & 57.30 \\
\hline Inpago 8 (G24)* & $100.00 \mathrm{a}$ & $86.66 \mathrm{c}$ & $93.33 \mathrm{a}$ & 0.80 & Tolerant & 97.45 \\
\hline Inpago $10(G 25) *$ & $100.00 \mathrm{a}$ & $73.33 \mathrm{f}$ & $86.67 \mathrm{~b}$ & 0.57 & Tolerant & 90.15 \\
\hline Inpago 11 (G26)* & $100.00 \mathrm{a}$ & $66.66 \mathrm{~g}$ & $83.33 \mathrm{c}$ & 0.48 & Susceptible & 71.90 \\
\hline Inpari 39 (G27)* & $100.00 \mathrm{a}$ & $73.33 \mathrm{f}$ & $86.67 \mathrm{~b}$ & 0.57 & Tolerant & 93.80 \\
\hline
\end{tabular}

Remarks: * (Control varieties: drought-tolerant), $\mathrm{CV}=12.59 \%$

Mean values within the same column followed by similar small letter are not significantly different at 5\% DMRT.

Criteria of tolerant index: $\mathrm{Ti}>0.5=$ tolerant and $\mathrm{Ti}<0.5=$ susceptible 


\subsection{Plant Height}

Water stress created by the application of $20 \%$ PEG did not affect the plant height of all rice genotypes tested (Table 3). All genotypes were tolerant to water stress except for $\mathrm{G}_{1}$ and $\mathrm{G}_{22}$.

The tolerant genotypes had a resistant probability of 4.05-93.80\%. However, there were 8 local rice genotypes $\left(\mathrm{G}_{10}, \mathrm{G}_{12}, \mathrm{G}_{4}, \mathrm{G}_{8}, \mathrm{G}_{21}, \mathrm{G}_{3}, \mathrm{G}_{13}\right.$, and $\left.\mathrm{G}_{5}\right)$ with a resistant probability of $>60 \%$ and higher than that of 3 tolerant rice varieties $\left(\mathrm{G}_{24}, \mathrm{G}_{26}\right.$, and $\left.\mathrm{G}_{27}\right)$.

Table 3. Plant height, tolerant index, and the resistant probability of 23 genotypes of local rice of Deli Serdang district and 4 varieties of drought-tolerant in response to PEG, 4 weeks after planting

\begin{tabular}{|c|c|c|c|c|c|c|}
\hline \multirow[t]{2}{*}{ Genotype } & \multicolumn{2}{|c|}{ Plant height (cm) } & \multirow{2}{*}{$\begin{array}{l}\text { Genotype } \\
\text { Mean }\end{array}$} & \multirow{2}{*}{$\begin{array}{l}\text { Tolerant } \\
\text { Index }\end{array}$} & \multirow[t]{2}{*}{ Criteria } & \multirow{2}{*}{$\begin{array}{c}\text { Resistant } \\
\text { Probability } \\
(\%)\end{array}$} \\
\hline & PEG $0 \%$ & PEG $20 \%$ & & & & \\
\hline Kuku Balam $\left(\mathrm{G}_{1}\right)$ & 30.00 & 12.66 & $21.33 \mathrm{k}$ & 0.13 & Susceptible & 2.55 \\
\hline Siudang $\left(\mathrm{G}_{2}\right)$ & 35.83 & 34.33 & $35.08 \mathrm{ab}$ & 0.80 & Tolerant & 3.05 \\
\hline Pandan Wangi $\left(\mathrm{G}_{3}\right)$ & 35.00 & 37.73 & $36.37 \mathrm{~b}$ & 0.99 & Tolerant & 75.55 \\
\hline Sigambiri merah $\left(\mathrm{G}_{4}\right)$ & 31.00 & 39.16 & $35.08 \mathrm{~b}$ & 1.20 & Tolerant & 90.15 \\
\hline Sigantang $\left(\mathrm{G}_{5}\right)$ & 33.66 & 36.16 & $34.92 \mathrm{~b}$ & 0.94 & Tolerant & 64.60 \\
\hline Sibelacan $\left(\mathrm{G}_{6}\right)$ & 34.33 & 34.83 & $34.58 \mathrm{~b}$ & 0.86 & Tolerant & 53.65 \\
\hline Gemuruh $\left(\mathrm{G}_{7}\right)$ & 29.00 & 30.66 & $29.83 \mathrm{ef}$ & 0.79 & Tolerant & 31.75 \\
\hline Sipingkol $\left(\mathrm{G}_{8}\right)$ & 28.33 & 36.33 & $32.33 \mathrm{~cd}$ & 1.13 & Tolerant & 86.50 \\
\hline Padi Hitam $\left(\mathrm{G}_{9}\right)$ & 30.33 & 32.66 & $31.50 \mathrm{de}$ & 0.85 & Tolerant & 50.00 \\
\hline Sipirok $\left(\mathrm{G}_{10}\right)$ & 28.00 & 40.66 & $34.33 \mathrm{bc}$ & 1.44 & Tolerant & 97.45 \\
\hline Merah Wangi $\left(\mathrm{G}_{11}\right)$ & 25.66 & 26.50 & $26.08 \mathrm{j}$ & 0.66 & Tolerant & 24.45 \\
\hline Serang $\left(\mathrm{G}_{12}\right)$ & 34.00 & $41 . .00$ & $37.50 \mathrm{a}$ & 1.20 & Tolerant & 93.80 \\
\hline Ramos Putih $\left(\mathrm{G}_{13}\right)$ & 30.75 & 34.66 & 27.58 ghij & 0.95 & Tolerant & 68.25 \\
\hline Ramos Merah $\left(\mathrm{G}_{14}\right)$ & 29.00 & 25.66 & $27.33 \mathrm{hij}$ & 0.55 & Tolerant & 13.50 \\
\hline Arias $\left(G_{15}\right)$ & 30.00 & 34.50 & $27.25 \mathrm{ij}$ & 0.96 & Tolerant & 71.90 \\
\hline Maraisi $\left(\mathrm{G}_{16}\right)$ & 31.33 & 30.83 & $31.08 \mathrm{def}$ & 0.73 & Tolerant & 28.10 \\
\hline Sigambiri Putih $\left(\mathrm{G}_{17}\right)$ & 29.33 & 31.66 & $30.50 \mathrm{def}$ & 0.83 & Tolerant & 42.70 \\
\hline Sijambi $\left(\mathrm{G}_{18}\right)$ & 24.33 & 29.00 & $26.67 \mathrm{j}$ & 0.84 & Tolerant & 46.35 \\
\hline Tambur Kersik $\left(\mathrm{G}_{19}\right)$ & 32.33 & 27.00 & $29.67 \mathrm{efg}$ & 0.54 & Tolerant & 9.80 \\
\hline Sialus $\left(\mathrm{G}_{20}\right)$ & 29.66 & 32.66 & $31.17 \mathrm{def}$ & 0.87 & Tolerant & 57.30 \\
\hline Silayur $\left(\mathrm{G}_{21}\right)$ & 26.00 & 33.00 & 29.50 efgh & 1.02 & Tolerant & 79.20 \\
\hline Sirabut $\left(\mathrm{G}_{22}\right)$ & 30.00 & 13.50 & $19.50 \mathrm{k}$ & 0.15 & Susceptible & 6.20 \\
\hline Sigimbal $\left(\mathrm{G}_{23}\right)$ & 33.66 & 30.00 & $31.83 \mathrm{de}$ & 0.65 & Tolerant & 20.80 \\
\hline Inpago $8\left(G_{24}\right) *$ & 26.33 & 31.66 & 29.00 fghi & 0.92 & Tolerant & 60.95 \\
\hline Inpago $10\left(G_{25}\right)^{*}$ & 27.00 & 33.83 & 30.42 def & 1.03 & Tolerant & 82.85 \\
\hline Inpago $11\left(G_{26}\right) *$ & 26.00 & $24 . .83$ & $25.42 \mathrm{j}$ & 0.57 & Tolerant & 17.15 \\
\hline Inpari $39\left(\mathbf{G}_{27}\right)^{*}$ & 24.66 & 28.33 & $26.50 \mathrm{j}$ & 0.79 & Tolerant & 35.40 \\
\hline Mean PEG & $29.09 \mathrm{a}$ & $31.09 \mathrm{~b}$ & & & & \\
\hline
\end{tabular}

\subsection{Length and Number of Roots Protruding from Paraffin Layer}

Data of length and number of roots protruding from paraffin layer 4 weeks after planting are presented in Table 4. Roots of local rice from the 20\% PEG treatment group were shorter than that of $0 \%$ PEG group. Within the treatment group of $20 \%$ PEG, local rice genotype Arias $\left(\mathrm{G}_{15}\right)$ demonstrated the longest root, in contrast to genotype Inpago $8\left(\mathrm{G}_{24}\right)$ with the shortest root, 11.0 and $3.0 \mathrm{~cm}$ respectively. Water stress through the application of 20\% PEG reduced root length and the number of roots of rice variety Inpago $8\left(\mathrm{G}_{24}\right), 40$ and $75 \%$ respectively. Rice var. Inpago 8 is 
one of drought-tolerant rice varieties used for this experiment. Among all 27 rice genotypes tested, there were only 6 genotypes showing water stress tolerance. They were genotypes $\mathrm{G}_{2}, \mathrm{G}_{4}, \mathrm{G}_{7}, \mathrm{G}_{8}$, $\mathrm{G}_{9}$, and $\mathrm{G}_{15}$. It was interesting to note that 3 rice varieties tolerant to water stress $\left(\mathrm{G}_{25}, \mathrm{G}_{26}\right.$, and $\mathrm{G}_{27}$ ) had a lower probability to be drought-tolerant with a probability of $<60 \%$.

The number of roots protruding from paraffin layer varied between the rice genotypes. The highest number of roots was observed from local rice genotypes $G_{10}$ and $G_{17}$ with 4 roots observed at each pot. All 4 drought-tolerant rice varieties had a tolerant index lower than 0.5 according to the number of roots protruding from paraffin layer. Therefore, these four rice varieties fell into a category of susceptible to drought according to their root growth.

\subsection{Plant fresh and dry weight}

In general, PEG-induced water stress reduced plant fresh and dry weight of local rice genotypes and 4 drought-tolerant rice varieties (Table 5). According to plant fresh weight, all 23 local rice genotypes were susceptible to drought with tolerant index was lower than 0.5. However, seven genotypes showed a $>60 \%$ probability of drought-resistant according to plant fresh weight, i.eG $\mathrm{G}_{10}(93.80 \%), \mathrm{G}_{15}(90.15 \%), \mathrm{G}_{14}(86.50 \%), \mathrm{G}_{8}(82.85 \%), \mathrm{G}_{5}(79.20 \%), \mathrm{G}_{1}(75.55 \%)$ and $\mathrm{G}_{12}$ (71.90\%). A different response was observed in plant dry weight. Six rice genotypes, $\mathrm{G}_{3}, \mathrm{G}_{6}, \mathrm{G}_{11}$, $\mathrm{G}_{15}, \mathrm{G}_{20}$ dan $\mathrm{G}_{22}$ were tolerant to water stress. Eight local rice genotypes had a probability to be resistant to drought $\left(\mathrm{G}_{6}, \mathrm{G}_{22}, \mathrm{G}_{15}, \mathrm{G}_{20}, \mathrm{G}_{11}, \mathrm{G}_{3}, \mathrm{G}_{2}\right.$, and $\mathrm{G}_{21}$ ). Interestingly, $\mathrm{G}_{24}$ (Inpago 8), a drought-tolerant rice variety was considered susceptible according to plant fresh and dry weight.

\subsection{Proline Content}

PEG-induced water stress increased proline content in the leaf of local rice genotypes tested (Table 6). The highest proline content was observed form rice genotype $\mathrm{G}_{21}(6,404 \mu \mathrm{M} / \mathrm{g})$, followed by $\mathrm{G}_{19}(5,052 \mu \mathrm{M} / \mathrm{g}), \mathrm{G}_{10}(4,517 \mu \mathrm{M} / \mathrm{g}), \mathrm{G}_{14}(4,188 \mu \mathrm{M} / \mathrm{g}), \mathrm{G}_{1}(4,169 \mu \mathrm{M} / \mathrm{g})$ and $\mathrm{G}_{13}$ $(4,047 \mu \mathrm{M} / \mathrm{g})$. The proline content of these six local genotypes was higher than that of four drought-tolerant rice varieties.

All local rice genotypes studied were tolerant to water stress under the experimental condition except for genotypes $\mathrm{G}_{2}, \mathrm{G}_{4}, \mathrm{G}_{5}$, and $\mathrm{G}_{16}$ according to the value of tolerant index. However, a different response was observed for the percentage of drought resistance probability. There were nine local rice genotypes with $>60 \%$ drought resistance probability, i.e. $\mathrm{G}_{21}(97.45 \%)$, $\mathrm{G}_{19}(93.80 \%), \mathrm{G}_{1}(90.15 \%), \mathrm{G}_{14}(82.85 \%), \mathrm{G}_{10}(79.20 \%), \mathrm{G}_{13}(75.55 \%), \mathrm{G}_{7}(71.90 \%), \mathrm{G}_{20}(64.60 \%)$ and $\mathrm{G}_{3}(60.95 \%)$. Interestingly, these nine local genotypes showed higher probability of drought tolerance than that of two drought-tolerant varieties, Inpago $11\left(\mathrm{G}_{26}\right)$ and Inpari $39\left(\mathrm{G}_{27}\right)$. All genotypes tested except for Sigambiri Merah and Sigantang increased their proline content in response to drought stress. In addition, genotypes Sigambiri Merah and Sigantang showed proline 
content lower than that of other rice genotype tested, 0.23 and 0.18 respectively. Therefore, one of the criteria used to select resistant genotypes to drought at this research is high level of proline.

Seed germination mostly depends on the metabolic activities and the stimulation of growth hormones in seeds. Water availability is necessary for seed germination and insufficient water will inhibit the germination process. However, to some extent, drought-resistant seeds may germinate and grow under water stress conditions. The research reported here found significant differences in the germination rate of local rice tested. Four local rice genotypes were found to be tolerant to water stress with a germination rate higher than that of four drought-tolerant varieties, i.e. Ramos Merah (93.33\%) followed by Silayur, Sirabut, and Marasi with a 73.33\% germination rate for each genotype. Rice seed treated with PEG absorbed less water as PEG increased the osmotic potential of the growing media which resulted a reduction in germination percentage (Jatoi et al., 2014). The higher the concentration of PEG applied the lower the germination rate of two varieties of black rice tested (Nurmalasari, 2018).

The plant height of local rice was not affected by PEG under this experimental condition. Therefore, plant height would not be a good character to evaluate the drought resistance of rice genotype tested. However, it was interesting to note that plant height was higher in PEG-treated rice than the control group. This may result from a fast response to water once the seedlings were removed to the glass house for further growth. Slow germination process under water stress would reserve some of the resources from the endosperm and be used for later growth. In the other hands, rice seeds from the control treatment group undergone a high rate of metabolic process during germination in the presence of enough water. When these seedlings were removed from the glasshouse, they may have needed more energy and resources to adapt to the new environment with certain stagnancy in early rapid growth. Research has shown that drought-tolerant rice grew quite well with a relatively good plant height (Kumar et al., 2014; Larkunthod et al., 2018; Mejri et al., 2016).

Commonly, plant increases root cell division and elongation to reach water table in the soil under water stress. This has been known as one mechanism to adapt to the water deficiency (Allah et al., 2010). A significant difference is in the root length and the number of roots protruding from paraffin layer at 4 WAP was recorded between the PEG and the control treatment group. Rice genotype with a potential to be tolerant to drought had longer roots protruding from the paraffin though less amount of roots was recorded. Therefore, the amount of root protruding from the paraffin was not good enough to be used as an indicator for drought tolerance. 
Table 4. Length of roots and number of roots protruding from the paraffin layer, tolerant index, and resistant probability of 23 genotypes of local rice of Deli Serdang district and 4 varieties of drought-tolerant in response to PEG, 4 weeks after planting

\begin{tabular}{|c|c|c|c|c|c|c|c|c|c|c|c|c|}
\hline \multirow[t]{2}{*}{ Genotype } & \multicolumn{2}{|c|}{ Root length (cm) } & \multirow{2}{*}{$\begin{array}{c}\text { Genotype } \\
\text { Mean }\end{array}$} & \multirow{2}{*}{$\begin{array}{l}\text { Toleran } \\
\text { t Index }\end{array}$} & \multirow{2}{*}{$\begin{array}{l}\text { Crite } \\
\text {-ria }\end{array}$} & \multirow{2}{*}{$\begin{array}{l}\text { Resistant } \\
\text { Prob (\%) }\end{array}$} & \multicolumn{2}{|c|}{ Root number } & \multirow{2}{*}{$\begin{array}{c}\text { Genotype } \\
\text { Mean }\end{array}$} & \multirow{2}{*}{$\begin{array}{l}\text { Tolerant } \\
\text { Index }\end{array}$} & \multirow{2}{*}{$\begin{array}{l}\text { Crite- } \\
\text { ria }\end{array}$} & \multirow{2}{*}{$\begin{array}{l}\text { Resistant } \\
\text { Prob (\%) }\end{array}$} \\
\hline & PEG (0\%) & PEG $(20 \%)$ & & & & & PEG 0\% & PEG(20\%) & & & & \\
\hline Kuku Balam $\left(\mathrm{G}_{1}\right)$ & $0.3 \mathrm{opq}$ & $0.0 \mathrm{q}$ & $0.15 \mathrm{j}$ & 0.00 & $\mathrm{~S}$ & 2.55 & $2.00 \mathrm{~d}$ & $0.00 \mathrm{f}$ & $1.00 \mathrm{e}$ & 0.00 & $\mathrm{~S}$ & 2.55 \\
\hline Siudang $\left(\mathrm{G}_{2}\right)$ & 0.5 no & $6.0 \mathrm{~g}$ & $3.25 \mathrm{e}$ & 6.55 & $\mathrm{~T}$ & 97.45 & $2.00 \mathrm{~d}$ & $3.00 \mathrm{c}$ & $2.50 \mathrm{~cd}$ & 1.13 & $\mathrm{~T}$ & 82.85 \\
\hline Pandan Wangi $\left(\mathrm{G}_{3}\right)$ & 0.5 nop & $1.0 \mathrm{~lm}$ & $0.75 \mathrm{hij}$ & 0.18 & $\mathrm{~S}$ & 68.25 & $5.00 \mathrm{a}$ & $3.00 \mathrm{c}$ & $4.00 \mathrm{a}$ & 0.45 & $\mathrm{~S}$ & 53.65 \\
\hline Sigambiri merah $\left(\mathrm{G}_{4}\right)$ & $0.2 \mathrm{pq}$ & $3.0 \mathrm{j}$ & $1.60 \mathrm{fg}$ & 4.09 & $\mathrm{~T}$ & 93.80 & $1.00 \mathrm{e}$ & $2.00 \mathrm{~d}$ & $1.50 \mathrm{de}$ & 1.00 & $\mathrm{~T}$ & 71.90 \\
\hline Sigantang $\left(\mathrm{G}_{5}\right)$ & $0.0 \mathrm{q}$ & $0.3 \mathrm{opq}$ & $0.15 \mathrm{j}$ & 0.00 & $\mathrm{~S}$ & 6.20 & $0.00 \mathrm{f}$ & $1.00 \mathrm{e}$ & $0.50 \mathrm{~g}$ & 0.00 & $\mathrm{~S}$ & 6.20 \\
\hline Sibelacan $\left(\mathrm{G}_{6}\right)$ & $8.0 \mathrm{e}^{2}$ & $1.0 \mathrm{~lm}$ & $4.50 \mathrm{~d}$ & 0.01 & $\mathrm{~S}$ & 24.45 & $2.00 \mathrm{~d}$ & $3.00 \mathrm{c}$ & $2.50 \mathrm{~cd}$ & 1.13 & $\mathrm{~T}$ & 86.50 \\
\hline Gemuruh $\left(\mathrm{G}_{7}\right)$ & $0.7 \mathrm{mno}$ & $5.5 \mathrm{~h}$ & $3.10 \mathrm{e}$ & 3.92 & $\mathrm{~T}$ & 90.15 & $1.00 \mathrm{e}$ & $2.00 \mathrm{~d}$ & $1.50 \mathrm{de}$ & 1.00 & $\mathrm{~T}$ & 75.55 \\
\hline Sipingkol (G8) & $6.0 \mathrm{~g}$ & $8.23 \mathrm{e}$ & $7.12 \mathrm{~b}$ & 1.03 & $\mathrm{~T}$ & 82.85 & $4.00 \mathrm{~b}$ & $2.00 \mathrm{~d}$ & $3.00 \mathrm{~b}$ & 0.25 & $\mathrm{~S}$ & 39.05 \\
\hline Padi Hitam $\left(\mathrm{G}_{9}\right)$ & $11.0 \mathrm{c}$ & $10.0 \mathrm{~d}$ & $10.50 \mathrm{a}$ & 0.82 & $\mathrm{~T}$ & 79.20 & $2.00 \mathrm{~d}$ & $1.00 \mathrm{e}$ & $1.50 \mathrm{de}$ & 0.13 & $\mathrm{~S}$ & 31.75 \\
\hline Sipirok $\left(\mathrm{G}_{10}\right)$ & 1.21 & $1.0 \mathrm{~lm}$ & $1.10 \mathrm{gh}$ & 0.07 & $\mathrm{~S}$ & 60.95 & $2.00 \mathrm{~d}$ & $4.00 \mathrm{~b}$ & $3.00 \mathrm{~b}$ & 2.00 & & 90.15 \\
\hline Merah Wangi $\left(\mathrm{G}_{11}\right)$ & 0.5 nop & 0.5 nop & $0.50 \mathrm{hij}$ & 0.04 & $\mathrm{~S}$ & 46.35 & $1.00 \mathrm{e}$ & $1.00 \mathrm{e}$ & $1.00 \mathrm{e}$ & 0.25 & $\mathrm{~S}$ & 42.70 \\
\hline Serang $\left(\mathrm{G}_{12}\right)$ & $2.0 \mathrm{k}$ & $2.0 \mathrm{k}$ & $2.00 \mathrm{f}$ & 0.01 & $\mathrm{~S}$ & 28.10 & $3.00 \mathrm{c}$ & $1.00 \mathrm{e}$ & $2.00 \mathrm{~d}$ & 0.08 & $\mathrm{~S}$ & 28.10 \\
\hline Ramos Putih $\left(\mathrm{G}_{13}\right)$ & 0.5 nop & 0.4 nopq & $0.45 \mathrm{ij}$ & 0.02 & $\mathrm{~S}$ & 39.05 & $1.00 \mathrm{e}$ & $1.00 \mathrm{e}$ & $1.00 \mathrm{e}$ & 0.25 & $\mathrm{~S}$ & 46.35 \\
\hline Ramos Merah $\left(\mathrm{G}_{14}\right)$ & 0.5 nop & $1.0 \mathrm{~lm}$ & $0.75 \mathrm{hij}$ & 0.18 & $\mathrm{~S}$ & 71.90 & $1.00 \mathrm{e}$ & $3.00 \mathrm{c}$ & $2.00 \mathrm{~d}$ & 2.25 & $\mathrm{~T}$ & 93.80 \\
\hline Arias $\left(\mathrm{G}_{15}\right)$ & $10.0 \mathrm{~d}$ & $11.0 \mathrm{c}$ & $10.50 \mathrm{a}$ & 1.10 & $\mathrm{~T}$ & 86.50 & $3.00 \mathrm{c}$ & $3.00 \mathrm{c}$ & $3.00 \mathrm{~b}$ & 0.75 & $\mathrm{~T}$ & 64.60 \\
\hline Maraisi (G16) & $1.0 \mathrm{~lm}$ & $0.8 \mathrm{lmn}$ & $0.90 \mathrm{hi}$ & 0.05 & $\mathrm{~S}$ & 53.65 & $1.00 \mathrm{e}$ & $2.00 \mathrm{~d}$ & $1.50 \mathrm{de}$ & 1.00 & $\mathrm{~T}$ & 79.20 \\
\hline Sigambiri Putih $\left(\mathrm{G}_{17}\right)$ & 0.5 nop & $1.0 \mathrm{~lm}$ & $0.75 \mathrm{hij}$ & 0.18 & $\mathrm{~S}$ & 75.55 & $1.00 \mathrm{e}$ & $4.00 \mathrm{~b}$ & $2.50 \mathrm{~cd}$ & 4.00 & $\mathrm{~T}$ & 97.45 \\
\hline Sijambi $\left(\mathrm{G}_{18}\right)$ & $1.0 \mathrm{~lm}$ & $0.8 \mathrm{lmn}$ & $0.90 \mathrm{hi}$ & 0.06 & $\mathrm{~S}$ & 57.30 & $3.00 \mathrm{c}$ & $3.00 \mathrm{c}$ & $3.00 \mathrm{~b}$ & 0.75 & $\mathrm{~T}$ & 68.25 \\
\hline Tambur Kersik $\left(\mathrm{G}_{19}\right)$ & $20.0 \mathrm{a}$ & $0.0 \mathrm{q}$ & $10.00 \mathrm{a}$ & 0.00 & $\mathrm{~S}$ & 9.85 & $1.00 \mathrm{e}$ & $0.00 \mathrm{f}$ & $0.50 \mathrm{f}$ & 0.00 & $\mathrm{~S}$ & 9.85 \\
\hline Sialus $\left(\mathrm{G}_{20}\right)$ & $7.0 \mathrm{f}$ & $1.0 \mathrm{~lm}$ & $4.00 \mathrm{~d}$ & 0.01 & $\mathrm{~S}$ & 31.75 & $5.00 \mathrm{a}$ & $2.00 \mathrm{~d}$ & $3.50 \mathrm{ab}$ & 0.20 & $\mathrm{~S}$ & 35.40 \\
\hline Silayur $\left(\mathrm{G}_{21}\right)$ & 0.5 nop & 0.5 nop & 0.0 hij & 0.04 & $\mathrm{~S}$ & 50.00 & $2.00 \mathrm{~d}$ & $2.00 \mathrm{~d}$ & $2.00 \mathrm{~d}$ & 0.50 & $\mathrm{~T}$ & 57.30 \\
\hline Sirabut $\left(\mathrm{G}_{22}\right)$ & $12.0 \mathrm{~b}$ & $0.0 \mathrm{q}$ & $6.00 \mathrm{c}$ & 0.00 & $\mathrm{~S}$ & 13.50 & $2.00 \mathrm{~d}$ & $0.00 \mathrm{f}$ & $1.00 \mathrm{e}$ & 0.00 & $\mathrm{~S}$ & 13.50 \\
\hline Sigimbal $\left(\mathrm{G}_{23}\right)$ & 0.5 nop & $0.3 \mathrm{opq}$ & $0.40 \mathrm{ij}$ & 0.01 & $\mathrm{~S}$ & 35.40 & $2.00 \mathrm{~d}$ & $2.00 \mathrm{~d}$ & $2.00 \mathrm{~d}$ & 0.50 & $\mathrm{~T}$ & 60.95 \\
\hline Inpago $8\left(\mathbf{G}_{24}\right)^{*}$ & $5.0 \mathrm{i}$ & $3.0 \mathrm{j}^{\mathrm{N}}$ & $4.00 \mathrm{~d}$ & 0.16 & $\mathrm{~S}$ & 64.60 & $4.00 \mathrm{~b}$ & $1.00 \mathrm{e}$ & $2.50 \mathrm{~cd}$ & 0.06 & $\mathrm{~S}$ & 24.45 \\
\hline Inpago $10\left(\mathbf{G}_{25}\right) *$ & $1.0 \mathrm{~lm}$ & 0.5 nop & 0.75 hij & 0.02 & $\mathrm{~S}$ & 42.70 & $1.00 \mathrm{e}$ & $1.00 \mathrm{e}$ & $1.00 \mathrm{e}$ & 0.25 & $\mathrm{~S}$ & 50.00 \\
\hline Inpago $11\left(\mathrm{G}_{26}\right) *$ & 0.5 nop & $0.0 \mathrm{q}$ & $0.25 \mathrm{j}$ & 0.00 & $\mathrm{~S}$ & 17.15 & $1.00 \mathrm{e}$ & $0.00 \mathrm{f}$ & $0.50 \mathrm{f}$ & 0.00 & $\mathrm{~S}$ & 17.15 \\
\hline Inpari $39\left(\mathbf{G}_{27}\right)^{*}$ & 0.5 nop & $0 \mathrm{q}$ & $0.25 \mathrm{j}$ & 0.00 & $\mathrm{~S}$ & 20.80 & $1.00 \mathrm{e}$ & $0.00 \mathrm{f}$ & $0.50 \mathrm{f}$ & 0.00 & $\mathrm{~S}$ & 20.80 \\
\hline Mean PEG & $3.39 \mathrm{a}$ & $2.18 \mathrm{~b}$ & & & & & 2.00 & 1.74 & & & & \\
\hline
\end{tabular}

Remarks: * (Control varieties: drought-tolerant). Mean values within the same column followed by similar small letter are not significantly different at $5 \%$ DMRT.

Criteria of tolerant index: $\mathrm{Ti}>0.5=$ tolerant $(\mathrm{T})$ and $\mathrm{Ti}<0.5=$ susceptible $(\mathrm{S})$. CV for root length $=21.85 \%$; CV for root number $=26.68 \%$ 
Table 5. Plant fresh and dry weight, tolerant index, and resistant probability of 23 genotypes of local rice of Deli Serdang district and 4 varieties of drought-tolerant in response to PEG, 4 weeks after planting

\begin{tabular}{|c|c|c|c|c|c|c|c|c|c|c|c|c|}
\hline \multirow[t]{2}{*}{ Genotype } & \multicolumn{2}{|c|}{ Fresh weight (g) } & \multirow{2}{*}{$\begin{array}{c}\text { Genotype } \\
\text { Mean }\end{array}$} & \multirow{2}{*}{$\begin{array}{l}\text { Toleran } \\
\text { t Index }\end{array}$} & \multirow{2}{*}{$\begin{array}{l}\text { Crite } \\
\text {-ria }\end{array}$} & \multirow{2}{*}{$\begin{array}{l}\text { Resistant } \\
\text { Prob (\%) }\end{array}$} & \multicolumn{2}{|c|}{ Dry weight (g) } & \multirow{2}{*}{$\begin{array}{c}\text { Genotype } \\
\text { Mean }\end{array}$} & \multirow{2}{*}{$\begin{array}{l}\text { Tolerant } \\
\text { Index }\end{array}$} & \multirow{2}{*}{$\begin{array}{l}\text { Crite- } \\
\text { ria }\end{array}$} & \multirow{2}{*}{$\begin{array}{l}\text { Resistant } \\
\text { Prob (\%) }\end{array}$} \\
\hline & PEG (0\%) & PEG $(20 \%)$ & & & & & PEG 0\% & PEG 20\% & & & & \\
\hline Kuku Balam $\left(\mathrm{G}_{1}\right)$ & $0.46 \mathrm{c}$ & $0.16 \mathrm{q}$ & $0.31 \mathrm{~b}$ & 0.29 & $\mathrm{~S}$ & 75.55 & $0.16 \mathrm{~b}$ & $0.10 \mathrm{~g}$ & $0.13 \mathrm{a}$ & 0.42 & $\mathrm{~S}$ & 53.65 \\
\hline Siudang $\left(\mathrm{G}_{2}\right)$ & 0.251 & $0.13 \mathrm{u}$ & $0.19 \mathrm{ij}$ & 0.25 & $\mathrm{~S}$ & 60.95 & $0.12 \mathrm{e}$ & $0.09 \mathrm{~h}$ & $0.11 \mathrm{c}$ & 0.45 & $\mathrm{~S}$ & 64.60 \\
\hline Pandan Wangi $\left(\mathrm{G}_{3}\right)$ & $0.16 \mathrm{q}$ & $0.11 \mathrm{w}$ & $0.14 \mathrm{~m}$ & 0.15 & $\mathrm{~S}$ & 17.15 & $0.08 \mathrm{i}$ & $0.08 \mathrm{i}$ & $0.08 \mathrm{k}$ & 0.53 & $\mathrm{~T}$ & 68.25 \\
\hline Sigambiri merah $\left(\mathrm{G}_{4}\right)$ & $0.32 \mathrm{~g}$ & $0.10 \mathrm{w}$ & $0.21 \mathrm{gh}$ & 0.21 & $\mathrm{~S}$ & 46.35 & $0.12 \mathrm{e}$ & $0.07 \mathrm{j}$ & $0.10 \mathrm{~cd}$ & 0.27 & $\mathrm{~S}$ & 35.40 \\
\hline Sigantang $\left(\mathrm{G}_{5}\right)$ & $0.48 \mathrm{~b}$ & $0.10 \mathrm{w}$ & $0.29 \mathrm{~cd}$ & 0.29 & $\mathrm{~S}$ & 79.20 & $0.17 \mathrm{a}$ & $0.08 \mathrm{i}$ & $0.13 \mathrm{a}$ & 0.25 & $\mathrm{~S}$ & 24.45 \\
\hline Sibelacan $\left(\mathrm{G}_{6}\right)$ & $0.21 \mathrm{o}$ & $0.13 \mathrm{u}$ & $0.17 \mathrm{kl}$ & 0.22 & $\mathrm{~S}$ & 50.00 & $0.08 \mathrm{i}$ & $0.11 \mathrm{f}$ & $0.10 \mathrm{~cd}$ & 1.01 & $\mathrm{~T}$ & 93.80 \\
\hline Gemuruh $\left(\mathrm{G}_{7}\right)$ & $0.17 \mathrm{q}$ & $0.10 \mathrm{w}$ & $0.14 \mathrm{~m}$ & 0.14 & $\mathrm{~S}$ & 13.50 & $0.07 \mathrm{j}$ & 0.051 & $0.06 \mathrm{fg}$ & 0.24 & $\mathrm{~S}$ & 20.80 \\
\hline Sipingkol $\left(\mathrm{G}_{8}\right)$ & $0.30 \mathrm{i}^{\mathrm{T}}$ & $0.14 \mathrm{t}$ & $0.22 \mathrm{fg}$ & 0.31 & $\mathrm{~S}$ & 82.85 & $0.13 \mathrm{~d}$ & $0.09 \mathrm{~h}$ & $0.11 \mathrm{c}$ & 0.42 & $\mathrm{~S}$ & 57.30 \\
\hline Padi Hitam $\left(\mathrm{G}_{9}\right)$ & $0.26 \mathrm{jk}$ & $0.12 \mathrm{v}$ & $0.19 \mathrm{ij}$ & 0.23 & $\mathrm{~S}$ & 53.65 & $0.13 \mathrm{~d}$ & $0.07 \mathrm{j}$ & $0.10 \mathrm{ij}$ & 0.25 & $\mathrm{~S}$ & 28.10 \\
\hline Sipirok $\left(\mathrm{G}_{10}\right)$ & $0.55 \mathrm{a}$ & $0.10 \mathrm{w}$ & $0.33 \mathrm{a}$ & 0.33 & $\mathrm{~S}$ & 93.80 & $0.17 \mathrm{a}$ & $0.06 \mathrm{k}$ & $0.12 \mathrm{ab}$ & 0.14 & $\mathrm{~S}$ & 9.85 \\
\hline Merah Wangi $\left(\mathrm{G}_{11}\right)$ & $0.17 \mathrm{q}$ & $0.11 \mathrm{w}$ & $0.14 \mathrm{~m}$ & 0.15 & $\mathrm{~S}$ & 20.80 & $0.06 \mathrm{k}$ & $0.07 \mathrm{j}$ & $0.07 \mathrm{f}$ & 0.54 & $\mathrm{~T}$ & 75.55 \\
\hline Serang $\left(\mathrm{G}_{12}\right)$ & $0.43 \mathrm{e}$ & $0.10 \mathrm{w}$ & $0.26 \mathrm{e}$ & 0.27 & $\mathrm{~S}$ & 71.90 & $0.16 \mathrm{~b}$ & $0.08 \mathrm{i}$ & $0.12 \mathrm{ab}$ & 0.27 & $\mathrm{~S}$ & 39.05 \\
\hline Ramos Putih $\left(\mathrm{G}_{13}\right)$ & $0.35 \mathrm{f}$ & $0.11 \mathrm{w}$ & $0.23 \mathrm{f}$ & 0.25 & $\mathrm{~S}$ & 64.60 & $0.09 \mathrm{~h}$ & $0.06 \mathrm{k}$ & 0.08 ef & 0.27 & $\mathrm{~S}$ & 42.70 \\
\hline Ramos Merah $\left(\mathrm{G}_{14}\right)$ & $0.45 \mathrm{~d}$ & $0.11 \mathrm{w}$ & $0.28 \mathrm{~d}$ & 0.31 & $\mathrm{~S}$ & 86.50 & $0.17 \mathrm{a}$ & $0.09 \mathrm{~h}$ & $0.13 \mathrm{a}$ & 0.32 & $\mathrm{~S}$ & 46.35 \\
\hline Arias $\left(\mathrm{G}_{15}\right)$ & $0.23 \mathrm{~m}$ & $0.16 \mathrm{q}$ & $0.20 \mathrm{hj}$ & 0.31 & $\mathrm{~S}$ & 90.15 & $0.12 \mathrm{e}$ & $0.12 \mathrm{e}$ & $0.12 \mathrm{ab}$ & 0.80 & $\mathrm{~T}$ & 86.50 \\
\hline Maraisi (G16) & $0.26 \mathrm{k}$ & $0.11 \mathrm{w}$ & $0.19 \mathrm{ijk}$ & 0.20 & $\mathrm{~S}$ & 39.05 & $0.13 \mathrm{~d}$ & $0.07 \mathrm{j}$ & $0.10 \mathrm{~cd}$ & 0.25 & $\mathrm{~S}$ & 31.75 \\
\hline Sigambiri Putih $\left(\mathrm{G}_{17}\right)$ & $0.31 \mathrm{~h}$ & $0.12 \mathrm{v}$ & $0.22 \mathrm{~g}$ & 0.26 & $\mathrm{~S}$ & 68.25 & $0.10 \mathrm{~g}$ & 0.051 & 0.08 ef & 0.17 & $\mathrm{~S}$ & 13.50 \\
\hline Sijambi $\left(G_{18}\right)$ & $0.22 \mathrm{n}$ & $0.10 \mathrm{w}$ & 0.161 & 0.16 & $\mathrm{~S}$ & 24.45 & $0.13 \mathrm{~d}$ & 0.051 & $0.09 \mathrm{e}$ & 0.13 & $\mathrm{~S}$ & 6.20 \\
\hline Tambur Kersik (G19) & $0.27 \mathrm{j}$ & $0.10 \mathrm{w}$ & $0.19 \mathrm{ijk}$ & 0.19 & $\mathrm{~S}$ & 31.75 & $0.07 \mathrm{j}$ & $0.06 \mathrm{k}$ & $0.07 \mathrm{f}$ & 0.34 & $\mathrm{~S}$ & 50.00 \\
\hline Sialus $\left(\mathrm{G}_{20}\right)$ & $0.10 \mathrm{w}$ & $0.10 \mathrm{w}$ & 0.10 no & 0.10 & $\mathrm{~S}$ & 2.55 & $0.04 \mathrm{~m}$ & $0.06 \mathrm{k}$ & $0.05 \mathrm{~g}$ & 0.60 & $\mathrm{~T}$ & 79.20 \\
\hline Silayur $\left(\mathrm{G}_{21}\right)$ & $0.10 \mathrm{w}$ & $0.10 \mathrm{w}$ & 0.10 no & 0.10 & $\mathrm{~S}$ & 6.20 & $0.04 \mathrm{~m}$ & 0.051 & $0.05 \mathrm{~g}$ & 0.42 & $\mathrm{~S}$ & 60.95 \\
\hline Sirabut $\left(\mathrm{G}_{22}\right)$ & $0.17 \mathrm{q}$ & $0.15 \mathrm{~s}$ & 0.161 & 0.24 & $\mathrm{~S}$ & 57.30 & $0.10 \mathrm{~g}$ & $0.11 \mathrm{f}$ & $0.11 \mathrm{c}$ & 0.81 & $\mathrm{~T}$ & 90.15 \\
\hline Sigimbal $\left(\mathrm{G}_{23}\right)$ & $0.22 \mathrm{n}$ & $0.10 \mathrm{w}$ & 0.161 & 0.16 & $\mathrm{~S}$ & 28.10 & $0.10 \mathrm{~g}$ & $0.03 \mathrm{n}$ & $0.07 \mathrm{f}$ & 0.06 & $\mathrm{~S}$ & 2.55 \\
\hline Inpago $8\left(\mathbf{G}_{24}\right)^{*}$ & $0.22 \mathrm{n}$ & $0.12 \mathrm{v}$ & $0.17 \mathrm{kl}$ & 0.20 & $\mathrm{~S}$ & 42.70 & $0.08 \mathrm{i}$ & 0.051 & $0.07 \mathrm{f}$ & 0.21 & $\mathrm{~S}$ & 17.15 \\
\hline Inpago $10\left(\mathbf{G}_{25}\right)^{*}$ & $0.23 \mathrm{~m}$ & $0.11 \mathrm{w}$ & $0.17 \mathrm{kl}$ & 0.19 & $\mathrm{~S}$ & 35.40 & $0.08 \mathrm{i}$ & $0.08 \mathrm{i}$ & $0.08 \mathrm{ef}$ & 0.53 & $\mathrm{~T}$ & 71.90 \\
\hline Inpago $11\left(G_{26}\right)^{*}$ & $0.13 \mathrm{u}$ & $0.11 \mathrm{w}$ & $0.12 \mathrm{n}$ & 0.13 & $\mathrm{~S}$ & 9.85 & $0.06 \mathrm{k}$ & $0.08 \mathrm{i}$ & $0.07 \mathrm{f}$ & 0.71 & $\mathrm{~T}$ & 82.85 \\
\hline Inpari $39\left(\mathbf{G}_{27}\right)^{*}$ & $0.16 \mathrm{q}$ & $0.20 \mathrm{p}$ & $0.18 \mathrm{jkl}$ & 0.36 & $\mathrm{~S}$ & 97.45 & $0.06 \mathrm{k}$ & $0.15 \mathrm{c}$ & $0.11 \mathrm{c}$ & 2.50 & $\mathrm{~T}$ & 97.45 \\
\hline Mean PEG & $0.27 \mathrm{a}$ & $0.12 \mathrm{~b}$ & & & & & $0.11 \mathrm{a}$ & $0.08 \mathrm{~b}$ & & & & \\
\hline
\end{tabular}

Remarks: * (Control varieties: drought-tolerant). Mean values within the same column followed by similar small letter are not significantly different at $5 \%$ DMRT.

Criteria of tolerant index: $\mathrm{Ti}>0.5=$ tolerant $(\mathrm{T})$ and $\mathrm{Ti}<0.5=$ susceptible $(\mathrm{S}), \mathrm{CV}$ for plant fresh weight $=21.02 \%$; CV for plant dry weight $=21.70$ 
Table 6. Proline content, tolerant index, and resistant probability of 23 genotypes of local rice of Deli Serdang district and 4 varieties of drought-tolerant in response to PEG, 4 weeks after planting

\begin{tabular}{|c|c|c|c|c|c|c|}
\hline \multirow[t]{2}{*}{ Genotype } & \multicolumn{2}{|c|}{ Proline content $(\mu \mathrm{M} / \mathrm{g})$} & \multirow{2}{*}{$\begin{array}{c}\text { Genotype } \\
\text { Mean }\end{array}$} & \multirow{2}{*}{$\begin{array}{l}\text { Tolerant } \\
\text { Index }\end{array}$} & \multirow[t]{2}{*}{ Criteria } & \multirow{2}{*}{$\begin{array}{c}\text { Resistant } \\
\text { Probability } \\
\text { (\%) }\end{array}$} \\
\hline & PEG $0 \%$ & PEG $20 \%$ & & & & \\
\hline Kuku Balam (G1) & 1.424 & 4.169 & 2.79 & 1.91 & Tolerant & 90.15 \\
\hline Siudang (G2) & 1.671 & 2.094 & 1.88 & 0.40 & Susceptible & 13.50 \\
\hline Pandan Wangi (G3) & 2.028 & 3.672 & 2.85 & 1.04 & Tolerant & 60.95 \\
\hline Sigambiri merah (G4) & 1.869 & 1.671 & 1.77 & 0.23 & Susceptible & 6.20 \\
\hline Sigantang (G5) & 2.047 & 1.549 & 1.79 & 0.18 & Susceptible & 2.55 \\
\hline Sibelacan (G6) & 1.963 & 2.911 & 2.43 & 0.67 & Tolerant & 35.40 \\
\hline Gemuruh (G7) & 1.474 & 3.324 & 2.39 & 1.17 & Tolerant & 71.90 \\
\hline Sipingkol (G8) & 1.587 & 2.601 & 2.09 & 0.67 & Tolerant & 39.05 \\
\hline Padi Hitam (G9) & 1.268 & 2.113 & 1.69 & 0.55 & Tolerant & 28.10 \\
\hline Sipirok (G10) & 2.113 & 4.517 & 3.31 & 1.51 & Tolerant & 79.20 \\
\hline Merah Wangi (G11) & 1.399 & 2.263 & 1.83 & 0.57 & Tolerant & 31.75 \\
\hline Serang (G12) & 2.686 & 2.019 & 2.35 & 0.24 & Susceptible & 9.85 \\
\hline Ramos Putih (G13) & 1.887 & 4.047 & 2.96 & 1.36 & Tolerant & 75.55 \\
\hline Ramos Merah (G14) & 1.794 & 4.188 & 2.99 & 1.53 & Tolerant & 82.85 \\
\hline Arias (G15) & 1.352 & 2.911 & 2.13 & 0.98 & Tolerant & 53.65 \\
\hline Maraisi (G16) & 1.812 & 2.160 & 1.98 & 0.40 & Susceptible & 17.15 \\
\hline Sigambiri Putih (G17) & 1.681 & 2.986 & 2.33 & 0.83 & Tolerant & 46.35 \\
\hline Sijambi (G18) & 1.427 & 2.225 & 1.82 & 0.54 & Tolerant & 24.45 \\
\hline Tambur Kersik (G19) & 1.747 & 5.052 & 3.39 & 2.28 & Tolerant & 93.80 \\
\hline Sialus (G20) & 1.418 & 3.155 & 2.28 & 1.09 & Tolerant & 64.60 \\
\hline Silayur (G21) & 1.578 & 6.404 & 3.99 & 4.06 & Tolerant & 97.45 \\
\hline Sirabut (G22) & 2.620 & 3.700 & 3.16 & 0.82 & Tolerant & 42.70 \\
\hline Sigimbal (G23) & 1.578 & 3.005 & 2.37 & 0.89 & Tolerant & 50.00 \\
\hline Inpago 8 (G24)* & 1.427 & 3.164 & 2.29 & 1.09 & Tolerant & 68.25 \\
\hline Inpago $10(\mathbf{G} 25)^{*}$ & 1.455 & 3.803 & 2.62 & 1.55 & Tolerant & 86.50 \\
\hline Inpago 11 (G26)* & 1.596 & 2.272 & 1.93 & 0.50 & Tolerant & 20.80 \\
\hline Inpari 39 (G27)* & 1.887 & 3.512 & 2.69 & 1.02 & Tolerant & 57.30 \\
\hline Mean PEG & 1.733 & 3.166 & & & & \\
\hline
\end{tabular}

Many rice seedlings with high amount of roots protruding from paraffin did not reach the Hoagland's solution and died. We found 6 local rice genotypes tolerant to water stress with root longer than that of drought-tolerant varieties control group. The longest root $(11 \mathrm{~cm})$ was recorded in genotype Arias with 3 roots protruded from paraffin layer. Our finding was in accordance with previous study that rice var. Batang Piaman, Cisokan, and Ceredek had longer roots in response to water stress (Rahmadianti et al., 2017). A similar phenomenon was reported in sorghum. A higher amount of roots protruding form paraffin layer was observed from a 20\% PEG 6000 treatment group compared to control treatment group. Water deficiency affected root length of sorghum. Five out of 10 tested sorghum genotypes were drought-tolerant based on their ability to protrude from paraffin layer (Chaniago et al., 2017).

A significant reduction in plant fresh and dry wight was recorded from the $20 \%$ PEG treatment group. Six local rice were tolerant to drought according to plant dry 
weight. It was Pandan Wangi, Sibelacan, Merah Wangi, Arias, Sialus dan Sirabut. Water stress resulted a reduction in plant growth as reflected by reduction in plant weight (Larkunthod et al., 2018; Sulistyo et al., 2016). Water deficiency affects plant physiological process leading to morphological changes. Plants respond through a reduction in leaf transpiration rate and stomatal enclosure due to loss of cell turgidity (Taiz \& Zeiger, 2006). Stomatal enclosure inhibits gas exchange, such as $\mathrm{CO}_{2}$ and $\mathrm{O}_{2}$, between plants and atmosphere through stomata (Liu et al., 2004) which will in turn reduce the photosynthesis and other physiological processes in the plants and will reduce biomass in the plant tissue (Sujinah \& Jamil, 2016). Reduction in the growth and development of rice plants is impaired by physiological and environmental tensions. Climate changes and shortage of water has become a major global issue in food production. Drought may limit plant growth through alteration in physiological and biochemical process at various levels from cellular to a whole plant (Rahim et al., 2020). Water balance during cropping seasons determines plant growth and yield. Insufficient amount of water reduced yield and farmers' economic return (Dwiratna et al., 2018). However, a certain microorganism such as arbuscular mycorrhizae fungi could facilitate plant roots to develop better and acquire soil water table. Some species of arbuscular mycorrhizae fungi has demonstrated to be directly involved in the infection and intensify root growth of citronella plants in dry area of West Sumatera (Armansyah et al., 2018).

The proline content increased in response to water stress. Some genotypes showed a significant increase in proline content. Local rice genotype Silayur increased its proline as much as $75.35 \%$ over non-stressed control treatment. Increase in proline content in other genotypes varied and 9 genotypes showed an increase for over $50 \%$. Water stress as induced by PEG caused negative effect to plants' growth rate and cell enlargement through reduction in the rates of plant hormones and turgor pressure (Inostroza et al., 2015). Furthermore, drought stress may result in damage of cell membrane through stimulation of free radical formation in cells. Cell membrane impairment has also been used as a major parameter for cellular response to water stress (Sharifi et al., 2012; Rahim et al., 2020). However, a simple method of determining proline content is considered enough to determine plant response to water stress. Proline is an amino acid produced by plants exposed to drought stress and function as osmo-protectant to adjust cell osmolality (Nurmalasari, 2018). Increased level of proline enables drought-stressed plants to keep low water potentials, and play major role in maintaining cell turgor pressure and root growth (Zivcak et al., 2016). 
Various criteria might be used to determine whether rice genotypes are susceptible or tolerant to PEG-induced drought. Our data demonstrate various response to different criterion. For instance, local rice genotype Sirabut was classified as susceptible according to its plant height and root length. In contrast, genotype Sirabut showed to be tolerant in term of its germination percentage, plant dry weight, and proline content of leaf. The highest proline content was observed from genotype Sirabut. Therefore, we combined some criteria such as germination percentage, root length, plant dry weight, and proline content to determine to local rice genotype tolerant to drought.

\section{Conclusions}

Local rice of Deli Serdang subjected to PEG-induced water stress under the experimental condition revealed that 6 (six) genotypes were found to be tolerant to drought according to the tolerant index and drought-resistant probability, and high proline content. The genotypes were Gemuruh, Ramos Merah, Arias, Sialus, Silayur, and Sirabut. These six local rice genotypes will be used for further experiment in search for drought resistant rice genotypes.

\section{References}

Allah, A. A. A., Ammar, M. H., \& Badawi, A. T. (2010). Screening rice genotypes for drought resistance in Egypt. Journal of Plant Breeding and Crop Science, 2(7), 205215.

Armansyah, Anwar, A., Syarif, A., Yusniwati, \& Febriamansyah, R. (2018). Exploration and identification of the indigenous Arbuscular Mycorrhizae Fungi (AMF) in the rhizosphere of citronella (Andropogon nardus L.) in the dry land regions in West Sumatra Province, Indonesia. International Journal on Advanced Science, Engineering and Information Technology, 8(1), 85-92. https://doi.org/10.18517/ijaseit.8.1.2363

Barunawati, N., Maghfoer, M. D., Kendarini, N., \& Aini, N. (2016). Proline and specific root lenght as response to drought of wheat lines (Triticum aestivum L.). Agrivita, 38(3), 296-302. https://doi.org/10.17503/agrivita.v38i3.972

Bolaños, J., \& Edmeades, G. O. (1996). The importance of the anthesis-silking interval in breeding for drought tolerance in tropical maize. Field Crops Research, 48(1), 65-80. https://doi.org/10.1016/0378-4290(96)00036-6

Chaniago, I., Syarif, A., \& Riviona, P. (2017). Sorghum seedling drought response: In search of tolerant genotypes. International Journal on Advanced Science, Engineering and Information Technology, 7(3), 892-897. https://doi.org/10.18517/ijaseit.7.3.1303

Choi, W.-Y., Kang, S.-Y., Park, H.-K., Kim, S.-S., Lee, K.-S., Lee, K.-S., Shin, H.-T., \& Choi, S.-Y. (2000). Effects of water stress by PEG on growth and physiological traits in rice seedlings. Korean Journal of Crop Science, 45(2), 112-117.

Dwiratna, S., Bafdal, N., Asdak, C., \& Carsono, N. (2018). Study of runoff farming system to improve dryland cropping index in Indonesia. International Journal on Advanced Science, Engineering and Information Technology, 8(2), 390-396. https://doi.org/10.18517/ijaseit.8.2.3268 
Harper, J. E., \& Nicholas, J. C. (1976). Control of Nutrient Solution pH with an Ion Exchange System: Effect on Soybean Nodulation. Physiologia Plantarum, 38, 2428. https://doi.org/10.1111/j.1399-3054.1976.tb04852.x

Inostroza, L., Acuña, H., \& Tapia, G. (2015). Relationships between phenotypic variation in osmotic adjustment, water-use efficiency, and drought tolerance of seven cultivars of Lotus corniculatus L. Chilean Journal of Agricultural Research, 75(1), 3-12. https://doi.org/10.4067/S0718-58392015000100001

Iriany, R. N. A., Takdir, M. M., Yasin, H. E., \& Mejaya, M. (2005). Maize Genotype to drought stress. Journal of Indonesian Cereals Research Institute, 156-161.

Jatoi, S. A., Latif, M. M., Arif, M., Ahson, M., \& Siddiqui, S. U. (2014). Comparative assessment of wheat landraces against polyethylene glycol simulated drought stress. Science Technology and Development, 33(1), 1-6.

Jiang, W., \& Lafitte, R. (2007). Ascertain the effect of PEG and exogenous ABA on rice growth at germination stage and their contribution to selecting drought tolerant genotypes. In Asian Journal of Plant Sciences (Vol. 6, Issue 4, pp. 684-687). https://doi.org/10.3923/ajps.2007.684.687

Kumar, S., Dwivedi, S. K., Shing, S. S., Jha, S. K., Lekshmy, S., Elanchezhian, R., \& Bhatt, B. P. (2014). Identification of drought tolerant rice genotype by analysing drought tolerance indices and morpho-physiological traits. SABRAO Journal of Breeding and Genetics, 46(2), 217-230.

Larkunthod, P., Nounjan, N., Siangliw, J. L., Toojinda, T., Sanitchon, J., Jongdee, B., \& Theerakulpisut, P. (2018). Physiological responses under drought stress of improved drought- Tolerant rice lines and their parents. Notulae Botanicae Horti Agrobotanici Cluj-Napoca, 46(2), 679-687. https://doi.org/10.15835/nbha46211188

Liu, F., Jensen, C. R., \& Andersen, M. N. (2004). Drought stress effect on carbohydrate concentration in soybean leaves and pods during early reproductive development: its implication in altering pod set. Field Crops Research, 86(1), 1-13. https://doi.org/10.1016/s0065-2113(08)60477-0

Ludlow, M. M., \& Muchow, R. C. (1990). A Critical Evaluation of Traits for Improving Crop Yields in Water-Limited Environments. Advances in Agronomy, 107-153. https://doi.org/10.1016/s0065-2113(08)60477-0

Manavalan, L. P., Guttikonda, S. K., Phan Tran, L. S., \& Nguyen, H. T. (2009). Physiological and molecular approaches to improve drought resistance in soybean. Plant and Cell Physiology, 50(7), 1260-1276. https://doi.org/10.1093/pcp/pcp082

Mejri, M., Siddique, K. H. M., Saif, T., Abdelly, C., \& Hessini, K. (2016). Comparative effect of drought duration on growth, photosynthesis, water relations, and solute accumulation in wild and cultivated barley species. Journal of Plant Nutrition and Soil Science, 179(3), 327-335. https://doi.org/https://doi.org/10.1002/jpln.201500547

Muñoz, R., \& Quiles, M. J. (2013). Water deficit and heat affect the tolerance to high illumination in Hibiscus plants. International Journal of Molecular Sciences, 14(3), 5432-5444. https://doi.org/10.3390/ijms14035432

Neeraja, C. N., Malathi, S., \& Siddiq, E. A. (2006). Subspecies - Specific Microsatellite Markers for Rice (Oryza sativa L). Journal of Plant Biochemistry and Biotechnolog, 15(1), 39-41. https://doi.org/https://doi.org/10.1007/bf03321899

Nurmalasari, I. R. (2018). Kandungan Asam Amino Prolin Dua Varietas Padi Hitam pada Kondisi Cekaman Kekeringan. Gontor Agrotech Science Journal, 4(1), 29-44 http://dx.doi.org/10.21111/agrotech.v3i1.1898

Purbajanti, E. D., Kusmiyati, F., \& Fuskhah, E. (2017). Growth, yield and physiological characters of three types of indonesian rice under limited water supply. Asian 
Journal of Plant Sciences, $16(2), \quad 101-$ 108. https://doi.org/10.3923/ajps.2017.101.108

Rahim, D., Kalousek, P., Tahir, N., Vyhnánek, T., Tarkowski, P., Trojan, V., Abdulkhaleq, D., Ameen, A. H., \& Havel, L. (2020). In vitro assessment of kurdish rice genotypes in response to PEG-induced drought stress. Applied Sciences (Switzerland), 10(13), 1-21. https://doi.org/10.3390/app10134471

Rahmadianti, F., Violita, P., \& Eka, I. L. (2017). Respon Pertumbuhan dan Kandungan Asam Askorbat Beberapa Varietas Padi (Oryza sativa) Terhadap Cekaman Kekeringan. Journal Biosains, 1(2), 81-89.

Sabar, M., \& Arif, M. (2014). Phenotypic Response of Rice (Oryza sativa) Genotypes to Variable Moisture Stress Regimes. International Journal of Agriculture and Biology, 16(1), 32-40.

Sauro, J. (2007). Interactive Graph of the Standard Normal Curve. Measuring U. https://measuringu.com/normal curve/

Sharifi, P., Amirnia, R., Majidi, E., Hadi, H., Nakhoda, B., Alipoor, H. M., \& Moradi, F 2012). Relationship between drought stress and some antioxidant enzymes with cell membrane and chlorophyll stability in wheat lines. African Journal of Microbiology Research, 6(3), 617-623. https://doi.org/10.5897/ajmr11.1167

Singh, B. B., Mai-Kodomi, Y., \& Terao, T. (1999). A simple screening method for drought tolerance in cowpea. Indian Journal of Genetics and Plant Breeding, 59, 211-220.

Sujinah, \& Jamil, A. (2016). Mekanisme Respon Tanaman Padi terhadap Cekaman Kekeringan dan Varietas Toleran. Iptek Tanaman Pangan, 11(1), 1-8.

Sulistyo, R., Yunus, A., \& Nandariyah. (2016). Keragaman padi Ciherang M2 hasil radiasi Gamma pada stres kekeringan. Agrotech Res J, 5(1), 19-23.

Swapna, S., \& Shylaraj, K. S. (2017). Screening for Osmotic Stress Responses in Rice Varieties under Drought Condition. Rice Science, 24(5), 253-263. https://doi.org/10.1016/j.rsci.2017.04.004

Taiz, L., \& Zeiger, E. (2006). Plant Physiology, 4th Edition. Sinauer Associates, Inc.

Yang, L., Jiang, T., Fountain, J. C., Scully, B. T., Lee, R. D., Kemerait, R. C., Chen, S., $\&$ Guo, B. (2014). Protein profiles reveal diverse responsive signaling pathways in kernels of two maize inbred lines with contrasting drought sensitivity. International Journal of Molecular Sciences, 15(10), 18892-18918. https://doi.org/10.3390/ijms151018892

Zain, N. A. M., Ismail, M. R., Mahmood, M., Puteh, A., \& Ibrahim, M. H. (2014). Alleviation of water stress effects on $\mathrm{mr} 220$ rice by application of periodical water stress and potassium fertilization. Molecules, 19(2), 1795-1819. https://doi.org/10.3390/molecules19021795

Zivcak, M., Brestic, M., \& Sytar, O. (2016). Osmotic Adjustment and Plant Adaptation to Drought Stress. Drought Stress Tolerance in Plants, 1, 105-143. https://doi.org/10.1007/978-3-319-28899-4_5 